\author{
Миломир М. ГАВРИЛОВИЋ* \\ Београд
}

Оригинални научни рад

Примљен: 04. 10. 2016.

Прихваћен: 10. 02. 2017.

\title{
ОДЛИКЕ ЕНЦИКЛОПЕДИЈСКОГ МОДЕЛА ПРОЗЕ И МОГУЋНОСТИ ПРИМЕНЕ НА СРПСКИ РОМАН ДРУГЕ ПОЛОВИНЕ ХХ ВЕКА
}

\begin{abstract}
У овом раду је представљен енциклопедијски модел прозе, заснован на теоријским и херменеутичким премишљањима Н. Фраја, И. Калвина и С. Ерколина, такође пресек најзначајнијих одлика ове књижевне стратегије. У раду су, као енциклопедијски подухвати, приказани гласовити романи српске књижевности друге половине XX века: Прољећа Ивана Галеба (1957) В. Деснице, Пешчаник (1972) Д. Киша, Употреба човека (1976) А. Тишме, и Хазарски речник (1984) М. Павића.

Кључне речи: енциклопедијски модел прозе, тоталитет искуства, модернизам, постмодернизам, српски роман.
\end{abstract}

\section{1. Теоријски модел}

1.1. Тоталитет. Енциклопедијски модел у књижевности, према Нортропу Фрају (в. 2007), представља покушај да се у књижевном делу оствари слика света достатна да прикаже целину човековог искуства и сазнања, тоталност визије и, додали бисмо, слике света и човековог положаја у њему. Истакнуту одлику енциклопедијских форми, тоталитет (или тежњу за достизањем тоталитета), одређујемо као покушај да се у књижевном делу изрази целина човековог знања, искуства и емоције у оквиру једне или више области, односно, према првобитној Фрајевој замисли, свих могућих оквира.

1.2. Илузорност тоталитета као слике света. Фрајево виђење енциклопедизма се првенствено изводи из могућности да се целокупно искуство човека представи у једном тексту. Тај подухват утопијски постављеног циља је представљен на примеру Библије, али се односи и на Хомерове епове или Хесиодову Теогонију, али и на скупове литерарно-теолошких дела насталих

*gasha88gm@gmail.com 
у средњем веку, које одликује низ „stabilnih teoloških okvira koji su garantovali [...] jedinstvenost" (Ерколино 2016: 137). Такође, Фрајева дијалектика енциклопедичности кореспондира и са сликом света која је специфична за мит. У наведеним делима било је могуће сабрати целокупно искуство човека на једном тексту (или у скупу текстова/усмених целина), пре свега зато што је то искуство каналисао цивилизацијски филтер, као што је, рецимо, представа о свету античких Грка, или оптирао одређени центар моћи, пре свега религијски, као што је у средњем веку црква. С друге стране, мит је представљао цивилизацијску суму искуства, кроз досегнуто знање које је било у пуној мери довољно за представљање самог света и позиционирање човека, али и божанских представа и фигура у њему. Ипак, већ је појава Дидроове и Даламберове Енииклопедије концептуално указала да један текст или, у крајњој мери, свест човека који га пише, не могу досегнути до тоталитета искуства ни самога човека који се пројектује ка тексту, а камоли до једног цивилизацијског оквира сазнања, те се Фрајева концепција тоталитета унеколико мора изменити у (не)могућност тоталитета, јер се тоталитет искуства не може остварити у тексту, осим кроз илузију целине.

Енциклопедијски књижевни подухвати, како код наведених старих, класичних, тако и нововековних покушаја, јесу, заправо, један од пробних облика Вавилонске/Александријске библиотеке. Недостижни сан о сабраном целокупном човековом искуству на једном месту није идејно удаљен од Фрајове идеје о тоталитету, међутим, тај сан се одувек одређује као илузоран, премда и потребан и потраживан. Могућност да се сваколико искуство човека сабере на једном месту је једна од великих књижевних идеја, која је илузију свог остварења пронашла у читавом низу дела, од самих почетака књижевног исказивања, све до дела које се пишу и објављују и у XXI веку. Потреба за енциклопедијским репрезентом, односно синегдохом тоталитета људског искуства (јер се сам тоталитет не може досегнути, већ само кроз илузију представити), инхерентна је потреба људског духа, која своје капитално остварење проналази управо у књижевном тексту. У оквирима српске књижевности, такву тежњу је, како је то Предраг Петровић приметио у студији Откривање тоталитета: Романи Растка Петровића, најпотпуније исказао Растко Петровић у есеју „Мисао”: „Чути, као далеки и блиски шум, као брујање, све оно што људи говоре, што су говорили и што ће говорити људи свих времена и човечанстава; моћи прочитати све оно што су записале људске руке" (Петровић 2014: 76).

1.3. Смисао енциклопедијског подухвата. Теоријска могућност сабраног човековог искуства (тоталитета), активира и питање истинитости баштињеног сазнања. Издвајамо три могућа концепта истине који се обликују у енциклопедијским подухватима. Први концепт је истина вере, дакле, према Кристијану Олаху, „богоцентрична” истина (2012: 18), или, додали бисмо, истина која се одређује кроз „велики наратив”, јер произилази из велике приче у коју се верује и која се прихвата као модел непроменљиве слике света. У „Првој посланици Коринћанима” апостола Павла је записано: „Него што је лудо пред свијетом оно изабра Бог да посрами премудре” (Библија: 1 Кор. 
1.27). Стога, енциклопедије засноване на веровању у велики наратив, попут библијског текста, Хомерових и Хесиодових списа и многих митских космогонија, називамо „енциклопедијама лудих”, насупрот „енциклопедијама мудрих”, утемељеним на разуму, сазнању, које представљају продукт коперниканског убрзања човекове духовности. Енциклопедија лудих нуди искуство и слику света која произилази из великог наратива и садржи целокупно, неопходно и неупитно, искуство, које се не мора разумом проверити, и које je, у датом историјском пресеку развоја људског духа, довољно човеку да одреди сопствену позицију у свету. Дакле, првобитне енциклопедијске форме су засноване на веровању у велики наратив, док су потоње, енциклопедије мудрих, подухвати човековог рациа. Дакле, епски су подухват рационалистичко-просветитељске дијалектике, као што је Енцииклопедија Дидроа и Даламбера, и представљене су преко проверљивих информација и научно доказивих чињеница, односно, збиром текстова који се обраћају човековом разуму. Истина овог и настављачких подухвата би била „детронизована 'истина' (разума)”, „логоцентрична [...], јер њој је човек - а не Бог - мера” (Олах 2012: 19). Бога, за потребе овог рада, замењујемо било којом инстанцом у коју колектив верује, била она религијски или какав други цивилизацијски репер.

Ипак, у ХX веку, ни један од ова два модела није могуће активирати у првобитном облику. Криза великих наратива представља привид коначног усуда енциклопедијске форме. И вера и разум су детронизовани свеопштом дестабилизацијом великих наратива. Намера за досезањем тоталитета у Далмаберовој Енциклопедији (в. Ерколино 2016: 137) рационалистички је утемељена, и, на концу, представља илузорни пројекат архивирања објективног знања, које се не може сабрати, док је, рецимо, Библија заснована на наративу у који се верује у целокупном тоталитету испољавања тог текста, што је дијалектика и других религијских списа. Осим фундаменталних разлика, постоји разлика у самосвести подухвата: свест о енциклопедијском подухвату је могућа тек са падом великих наратива и успоном просветитељске парадигме, која је веровање покушала да замени и апстрахује рациом. Ни једна ни друга парадигма није достатна за XX век, после Фројда, Јунга, Бергсона, Ничеа - ни у модернизму ни у постмодернизму. Стога је питање истине, које се у првобитним енциклопедијским подухватима везује за веровање, а по просветитељству, за разум, унеколико релативизовано. Разбијање монолитности истине и умножавање, које доводи до хипертрофије облика истине, једна је од најзначајнијих тековина просветитељства.

Модерне енциклопедијске форме се не могу заснивати на веровању или на сазнању, јер су ове две категорије (као облици спознаје света и човека) значајно детронизоване, али оне опет пружају могућност да се у тексту представи искуство, као облик вере или сазнања. То су енциклопедије нужно „нелудих” и „немудрих”, а опет, по потреби и жељи лудих и мудрих, који у књижевном тексту виде јединствени простор за веру и сазнање. Енциклопедијски подухвати XX века нуде могућност људском духу да се приближи и мудрости и лудости, онолико колико му то његово читање текста, али и учи- 
тана дијалектика времена и историјског/филозофског и књижевног искуства дозвољавају. У представљеним односима видимо могућност за енциклопедију која се реализује на фону модернистичке поетике, док сматрамо да је енциклопедија мудрих у постмодернизму угрожена, управо због свеопште кризе и знања и искуства. Слично је и са енциклопедијом лудих, јер двадесетовековни сензибилитет човека условљава веровање преиспитивањем. Енциклопедијски подухвати, како они које смо приписали „лудима”, тако и они који су поверени „мудрима”, засновани су на илузији тоталитета човековог искуства и сазнања, и управо су, због кризе и сазнања и вере, могући само у књижевности. С друге стране, XX век је период у којем се енциклопедије лудих и мудрих прожимају, управо због кризе фундаменталних духовних потреба на основу којих су и настале.

\section{2. Роман као изабрани енциклопедијски жанр}

Роман представља онај жанр који у свеукупности својих облика може да хипертрофира у форму кадру да потенцијалну суму енциклопедијских података унесе у сопствену структуру. ${ }^{1}$ Итало Калвино сматра да се модерни роман остварује у виду енциклопедије и ту појаву назива „vokacijom našeg veka” (1989: 115). Енциклопедијски модел, како га Калвино схвата, остварује се у романескној форми „,kao metod saznanja i, pre svega, kao mreža povezivanja raznih zbivanja, osoba i stvari na svetu" (Исто: 115), дакле, и као наративна стратегија и као когнитивни обзор. Мрежа многоструких односа, која се уланчава у непредвидиве низове, претпоставља модел романа као отворене и нужно недовршене енциклопедије која похрањује многа сазнања и информације. Такав тип романа фундаментално је различит од класичне (научне) енциклопедије, која претпоставља знање које је унапред одређено фигурираним филтером, због чега и постоје енциклопедије какве познајемо, као што су енциклопедија спорта, цивилизације, флоре и фауне и многе друге. За разлику од Фраја, који тоталитет сматра најзначајнијом одликом енциклопедијског модела, Калвино сматра да је то управо могућност тоталитета као претпоставке, дакле, не књижевне концепције реализоване у тексту, већ идеје: „Danas više nije zamisliva sveukupnost, sem ako je potencijalna, pretpostavljena, višestruka" (Исто: 126).

\footnotetext{
${ }^{1}$ Дијахронијски, еп је дуго био изабрани енциклопедијски облик, од антике, све до краја средњег века, па и у епохама након њега, у ренесанси, бароку и класицизму. Међутим, парадигме се мењају, па и жанровске: још је Хегел тврдио да је роман еп модерног доба. Али и други жанрови могу, у XX веку, представљати енциклопедијски подухват, као, рецимо, Борхесове приповетке у којима се, често кроз иронијску оптику, разматра концепт тоталитета искуства и сазнања („Вавилонска библиотека”, „Пешчана књига”, „Фунес или памћење” и „Алеф”).
} 


\section{3. Одлике модела}

3.1. Синтеза/хомогеност искуства. Енциклопедијски модел тежи да се потврди кроз јединство, најчешће тематско-мотивско (Хазарски речник), али суштински се оно остварује преко слике света и цивилизацијског, односно естетског (интенционалног) филтера (Библија, Вуков Српски рјечник). Циљ енциклопедијске прозе је да пружи најширу могућу синтетичку репрезентацију тоталности стварног (уп. Ерколино 2016: 135). За Хомера и Хесиода је било могуће да представе ,zajednički sistem vrednosti i znanja” (Ерколино 2016: 129), који упућују на оквире једне цивилизације. Исто је покушао да учини и Вук Караџић. У средњовековним литерарно-теолошким списима један централизовани центар моћи је одређивао границе понуђеног (са)знања. У модерном времену то је немогуће јер је знање хипертрофирано и децентрирано, (што је очигледно већ на почетку века, код Џојса и Музила нарочито). Сходно томе, енциклопедијски се подухвати умножавају и мењају, јер више не постоји ,jedinstveni pogled na svet” (Ерколино 2016: 130), на шта указује и тематски и наративни развој романа у XX веку.

У Прољећима Ивана Галеба, рецимо, текст је представљен као привидна целина, односно као репрезент једног искуства, док се у Хазарском речнику и Пешчанику намеће питање да ли је текст целина или илузија целине.

3.2. Многострукост и илузорност подухвата. Модел енциклопедијског, према Калвину, подразумева и покушај да се досегну сва сазнања, који је у самом почетку одређен као илузоран, и да се „обухвати све могуће”, али тај подухват „ne uspeva da sebi nametne oblik i da dobije okvire i ostaje nedovršen” (1989: 127). У том случају, недостатан је облик (односно текстуална форма) и сама је намера неостварива. Калвино одређује Флоберов Бувар и Пекише најенциклопедијскијим романом који је икада написан, управо због потребе главних јунака да допру до свих могућих сазнања и њихове немогућности да замишљено остваре. Према томе, енциклопедијски модел прозе се реализује кроз многострукост перспектива и потенцијалних веза остварених на идејном, мотивском и структурном нивоу текста, и у привидном приказу многострукости (Калвинов термин) знања, искустава и података која се сабирају, каткад и кроз приказивање самог поступка, односно сабирања тих информација (концепција Кондуктера из Кишовог романа Башта, пепео). Вишеструкост се указује и на плану поступка. Пешчаник садржи четири различита приповедна модуса, Хазарски речник три оквира једне приче одређене различитим (цивилизацијским и верским) филтером (псеудо)историјских извора. У Употреби човека каталози допуњују нарацију децентрирану пред усудом великог наратива (Други светски рат, логорологија). Спискови сведоче и о унификовању јединки у ратним процесима, али и самом постојању човека у великом догађају, који опстаје, макар био минимално издвојен на списку, без обзира колико га историјски механизми дехуманизовали.

3.3. Усуд модерне енциклопедије. Пад великих наратива, као и недостатност оригиналне (антика, средњи век, мит) и секундарне (Дидроов и Даламберов подухват) енциклопедијске форме резултира стварањем читавог низа 
недовршених и парцијалних енциклопедијских дела. „Što je svet složeniji, veći su napori da se on reprezentuje i znanje neophodno za pokušaj sinteze" (Epколино 2016: 130). А енциклопедијски књижевни текстови и даље настају, чак и у (пост)постмодернизму. Јасно је да се филозофска теорија постмодернизма почесто не самерава са сопственим књижевним поступцима и изабраним темама. Поступак модернизма не може да (у потпуности) релативизује изабране инстанце, као што је, рецимо, човек, најчешће то ни не покушава; док постмодернизам претпоставља да може сваку инстанцу да релативизује, што се не остварује ни концептуално, нити се реализује у пуној мери у самом постмодернистичком тексту. Увек постоји онај који пише, и онај који ће прочитати, али и поред тога, присутне су и теме које нису релативизоване и деструиране. Ако су пали сви наративи и европска етика и духовност, онда су фашизам, гулаг, холокауст и логори прихваћени и етички коректни цивилизацијски облици и достигнућа - а нису. Зато и остаје потреба да се пише о тим темама, јер, у крајњој инстанци, ни човек ни његово искуство никада нису у потпуности релативизовани, што управо човека утемељује као наднаратив који се може у застрашујућим размерама декомпоновати и деструирати, али никада у пуној мери. Човек је та инстанца, а не бог, нити свет, која омогућава писање и када су велики наративи урушени, па и када се обесмисле енциклопедије лудих и мудрих, јер ни вера ни знање модерном човеку више нису довољни. Постојање човека одређује потребу за знањем и искуством, као и за писањем дела, а посебно енциклопедијских подухвата у којима се чува нешто од човековог искуства. Дакле, човек је (над)поетички кумир енциклопедијске прозе - њиме се оправдава и призивање целине и писање дела са илузијом тоталитета.

\section{4. Човек и памћење}

4.1. Енцииклопедијски књижевни текст као облик сазнања, памћења и археолошка форма. За Калвина је роман као енциклопедијски формат једна од могућности да се сачувају сазнања и искуства, при чему је очигледна потреба за наративом који може обухватити одређени искуствени регистар. И у модернизму (рушење великих наратива, искуство рата, апокалиптички контекст, криза западне културе и духовности, искуство авангарде) и у постмодернизму (ентропија, хипертрофија података, немогућност замишљања тоталитета, свеопшта релативизација, бар на нивоу теоријске концепције, не само великих наратива већ и самог човека и његовог искуства, немогућност да човек овлада подацима, псеудоисторичност) постоји опасност да се заборави искуствени обзор човека. Модерне енциклопедијске форме настају управо не би ли се нешто од тог искуства сачувало. Разлика је у позицији човека и поетичком императиву: енциклопедија модернизма је нужно непотпуна, јер се не може сабрати тоталитет искуства, због немогућности једне наративне свести то да учини, те се илузија тоталитета проналази у свести 
човека и приказу једног времена, а каткад се и јасно одустаје од такве концепције (Човек без својстава, Уликс, Дневник о Чарнојевићу, Људи говоре).

У модернизму се енциклопедијски подухват урушава пред немогућношћу да се прикаже свет и искуство у свом тоталитету, и не постоји поетички прокламована самосвест о самом покушају да се досегне тоталитет, већ се тематизује сам човек и његово искуство, барем у фрагменту испољавања. У постмодернизму су непотпуност енциклопедијске форме и илузија тоталитета програмски нужни, јер човек сада више не осећа, већ поуздано зна да се тоталитет не може досегнути и то је поетичка чињеница. Постмодернизам се ипак тврдоглаво држи енциклопедијског концепта, упркос хипертрофији информација и података (Објава броја 49 Томаса Пинчона, Киша и хартија Владимира Тасића), иако то делује „titanski pozamašno i suštinski pogrešivo” (Ерколино 2016: 128). Поетички императив се, као у поменута два српска романа, активира при покушају да се искуство и знање сачувају пред претњом „хипотетичке катаклизме” (Исто: 136) и да се омогући реконструкција света, чиме енциклопедија унесених података оправдава археолошки поступак реконструкције. Разлика између две епохе је у поетичкој позицији: модернизам је условно наиван, будући да са сигурношћу не зна да ли може да очува искуство, а постмодернизам покушава да очува искуство, са освешћеним сазнањем да је то неизводиво, барем не у потпуности. Обе парадигме активирају потребу за памћењем: модернизам отворено, а постмодернизам, упркос теоријским одредницама, доследно. Што се тумачених романа тиче, Десничин роман одређујемо као модернистички роман, док за Пешчаник, Употребу човека и Хазарски речник сматрамо да су настали, са различитим степеном прожимања, на размеђи високог модернизма и постмодерне поетике, при чему Павићев роман предњачи због активације поступака и дијалектике потоње поетичке парадигме.

4.2. Човек. У модернистичкој прози, човек, као и његово искуство представљају поетички центрум (односно искуство човека још увек није подложно поетичкој потреби за релативизовањем; потребно је приказати човека и његов искуствени видокруг, као сведочење о овоме свету и човеку). Следствено томе, енциклопедијска тенденција се може и развити у тој мери: као илузорна намера да се сећања и искуства отргну од заборава (Прољећа Ивана Галеба), или да се искуство очува пред налетом апокалиптичног догађаја (Употреба човека). С друге стране, тотализам у постмодернизму се делимично откида од човековог искуства, јер се и та инстанца релативизује, бар на нивоу теоријског промишљања. Тежња за тоталитетом се може препознати у поступку, као у Пешчанику, роману који представља транзитивни тренутак Кишове поетике са високог модернизма на постмодерну парадигму. Мада, у поменутом роману, ипак претрајава идеја одбране од заборава, јер je, као поетички императив, очигледна потреба за писањем о потопу панонских Јевреја у Другом светском рату. С друге стране, енциклопедијски текст постмодернизма је и покушај одбране од хипертрофије података (Киша и хартија). Без обзира на то што се идеја енциклопедизма мења и постаје утопијска (јер ни у модернизму ни у постмодернизму не може бити остварена), 
она и даље претрајава, као тежња инхерентна човеку и књижевности. Поново се са̂м човек (и његова свест), као инстанца која се не да у потпуности релативизовати, може сматрати разлогом писања енциклопедијских подухвата, с тим да модернизам реинтегрише субјекта, односно, човека, а то чини и постмодернизам, тврдећи да је реинтеграција немогућа.

Модернизам је наратив о искуству, а постмодернизам је и прича о искуству и знање да искуство не може да се очува. Самим тим, другој парадигми је потребан поступак, који може омогућити да се очува искуство. Свест о томе да се искуство не може очувати у тоталитету, односно да је упитно може ли се уопште одржати, помера фокус ка поступку. Премда се искуство не исцрпљује у њему (иначе би књижевно дело било само игра форме), већ у могућностима које поступак пружа (четири различита модуса приповедања у Пешчанику, обгрљена закључним (псеудо)документом, разнородни (псеудо)извори у Хазарском речнику и структура речника). Форма се поставља као последња линија одбране пред заборавом - уз свест о илузорности енциклопедијских књижевних подухвата, који се ипак упорно пишу. Дакле, у постмодернизму се осамостаљује поступак и активира паралелно с искуством које наративна свест одређује вредним да се очува. Узајамност форме и садржаја је очигледна: без садржаја који треба да се очува не би било ни поетичке потребе да се изнађе достатна форма, као што ни само искуство и сазнање које проистиче из тематског садржаја и регистра не би могло да опстане без одговарајуће форме.

\section{5. Енциклопедијски модел прозе и српски роман друге половине XX века}

Не можемо у овом раду опширно писати о изабраним романима које условно посматрамо као енциклопедијске подухвате, али можемо барем указати на неколико уочених појединости везаних за те романе. У Десничиним Прољећима Ивана Галеба представљен је један живот, од рођења, до симболичког краја (наратива о Ивану Галебу), симболичког новог почетка и одласка ка још једном прољећy. Наведени роман модернистичког проседеа, писан пре, а објављен по завршетку Другог светског рата, не представља, свакако, целокупни живот главног јунака. Успостављен је филтер који прераспоређује наративну грађу, а то је Галебова (нараторова) свест. Она из прошлости (али и садашњости) преузима одређена сећања, догађаје и емоције, по унутрашњем диктату свести главног лика романа. Појединац постаје репер према којем је одабрана грађа романа, а илузија тоталитета је очигледно присутна, јер се понуђени наратив обликује као коначна и непроменљива прича о једном животу.

Кишов Пешчаник потражује тоталитет у самом поступку. „Писмо Олги” представља синегдоху романа, сумирајући сегмент текста. У њега се уливају четири приповедна модуса, који представљају различите путеве ка целини, 
док само писмо јесте место из којег се изводе. Четири модуса су одређена различитим протоком информација, које се прожимају, али су дефинисане другачијим поступком или намером наратора активираним у одређеном модусу. У Пешчанику се поставља питање како испричати живот појединца (породице), и једно (псеудо)историјско време, у којем је писмо, документ, последњи траг о човеку. Одговор је реконструкција документа кроз археолошки поступак (в. Делић 1997), како појединачне визуре, тако и искуства времена, колектива и догађаја. На тај начин је представљена илузија тоталитета приказаног искуства и света.

Употребу човека Александра Тишме не карактеришемо као енциклопедијски роман. Радије у том роману проналазимо одређене тенденције које га могу приближити енциклопедијској прози. Није тешко, на трагу Хане Арент, у овом роману видети утемељење једне од великих прича XX века, везану за Други светски рат, логорологију и тоталитаризам. Нису ове теме, свакако, приказане у тоталитету својих испољавања, што је и поетичка чињеница овог романа: не може се живот човека који је одређен неким од ратних механизама дехуманизације приказати као целина, зато што се над причу надноси усуд великог наратива, који одређује и радњу и свет дела. Потребно је приказати чиме се тај наратив утврђује, а једно историјско време, представљено у књижевном тексту, декомпонује, што је заправо представљено судбином ликова. Стога је, барем када је о приказаним животима и слици света реч, потребан поступак који релативизује притисак великог наратива, као што је каталог којим су представљени оквири тог света и догађаји значајни за јунаке („Обиталишта”, „Вечерња издвајања” и други сегменти романа). У том поступку је сабрано изједначавање судбина - сви су једнаки пред усудом великог наратива у оквиру којег су (не сасвим потпуно) обезличени, али управо зато су неопходни подаци из каталога, ради разједначавања судбина у оквиру свеопште (зло)употребе тела, духа, односно човека. Каталози представљају илузорни покушај да се попишу искуства и догађаји представљеног света. Наратив се отима од усуда велике приче, а човек, дехуманизован до крајњих граница, ипак не нестаје са историјске позорнице.

Павићев Хазарски речник је прича колектива, као и псеудоисторијски наратив. У овом роману се илузија тоталитета објављује у поступку: сабрани су сви доступни извори о одређеној теми. Сама тема је непроучива (искуствени обзор Хазара и њихов псеудоисторијски ход) и недоступна сазнању, што је јасан миг постмодернистичком инсистирању на декомпоновању историјског наратива. Хазарско питање је идеална тема за енциклопедијски поступак: иако се тема отима проучавању, и суспендована је могућност да се у историју као велики наратив поверује, ипак се сумира цивилизацијско искуство и памћење једног колектива, кроз обликовање фрагмената њихове псеудоисторијске авантуре.

Дакле, о искуству које је представљено у сва четири романа (без обзира на оквире на које се обликовано искуство односи) није и не може бити написано све. Тоталитет није досегнут, али је кроз нарацију и манипулацију 
поступком пружено довољно информација и података да би се илузија тоталитета искуства наслутила.

\section{6. Завршна напомена}

Енциклопедијски подухвати у виду књижевног текста постоје колико и сама књижевност: од митских парадигми, све до савремене књижевне продукције. Поставља се питање зашто се таква дела пишу и зашто је у раду представљена тенденција инхерентна књижевности (и људском духу). Да бисмо, барем унеколико, покушали прецизно да одговоримо на постављено питање, надовезаћемо се на Слотердијкову реченицу: „Istorije imaju smisla samo u istoriji pripovedanja istorije" (1988: 29). Слично је и са историјом књижевности, која није, за разлику од саме књижевности, инхерентна потреба човекова. Књижевна енциклопедијска дела се и даље пишу, јер могу да понуде модерном човеку (читаоцу) искуство, у којем он може (поново) пронаћи веру или сазнање, или обоје. Ако је то, наравно, модерном човеку уопште и потребно.

\section{ЛИТЕРАТУРА}

Библија: Biblija ili Sveto pismo staroga i novoga zavjeta, prev. Đ. Daničić, V. Stefanović Karadžić, Beograd: Izdanje biblijskog društva.

Делић 1997: Ј. Делић, Кроз прозу Данила Киша. Ка поетищи Кишове прозе, књ. 2, Београд: БИГЗ.

Ерколино 2016: S. Erkolino, Enciklopedijski modus u modernističkoj i postmodernističkoj prozi, Polja, LXI/497, Novi Sad, 128-140.

Kalvino 1989: I. Kalvino, Američka predavanja, Novi Sad: „Bratstvo-Jedinstvo".

Олах 2012: К. Олах, Кюига-Бог: (Постмодерна) духовност у „Хазарском речнику” Милорада Павића, Београд: Институт за књижевност и уметност.

Петровић 2014: Р. Петровић, Изложбе, Чачак: Уметничка галерија „Надежда Петровић".

Sloterdijk 1988: P. Sloterdijk, Kopernikanska mobilizacija i ptolomejsko razoružanje, Novi Sad: „Bratstvo-Jedinstvo”.

Фрај 2007: Н. Фрај, Анатомија критике: четири есеја, Нови Сад: Orpheus, Београд: Нолит. 


\section{Milomir M. Gavrilović}

\section{CHARACTERISTICS OF THE ENCYCLOPEDIC MODEL OF PROSE AND THE POSSIBILITY OF ITS APPLICATION TO THE SERBIAN NOVEL OF THE SECOND HALF OF XX CENTURY}

\section{(Summary)}

This paper presents a theoretical model of encyclopedic prose (based on the research of N. Frye, I. Calvino and S. Ercolino), as well as the most important characteristics of the presented model of prose. The paper includes an analysis of several renowned novels of Serbian literature in the second half of the twentieth century: The Springs of Ivan Galeb (1957) by Vladan Desnica, Hourglass (1972) by Danilo Kiš, The Use of Man (1976) by Aleksandar Tišma, and Dictionary of the Khazars (1984) by Milorad Pavić, all of which are analyzed as encyclopedic types of modern prose. 